\title{
Literature Survey of Isotopic Abundance Data for 1991-1993*
}

\author{
Norman E. Holden \\ High Flux Beam Reactor \\ Reactor Division \\ Brookhaven National Laboratory \\ Upton, New York 11973 USA
}

\begin{abstract}
Data on isotopic abundance measurements and their variation in nature are complied for the time from 1991 to the present.
\end{abstract}

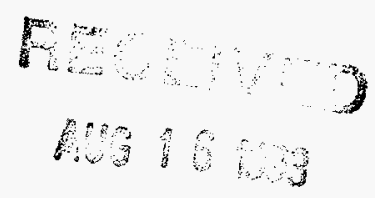

\section{Discussion}

I have compiled all of the data on isotopic abundance measurements and their variation in nature for the time period since the Hamburg General Assembly. Most of the data deals with the variations in the abundances as given by per mil deviations from some standard. As such, there are not of major interest to the Atomic Weights Commission. However, there were some measurements which are of general interest in this list. I comment below on those papers which should be under discussion at this year's meeting.

A number of the papers deal with the abundance values and their variation in meteorites and other non-terrestrial sources. These should be of interest to the subcommittee dealing with non-terrestrial material. If the subcommittee does not have access to all of these papers, I do have copies of all of the items listed in the attachment.

Among the papers which deal with the full set of abundance ratios and from which atomic weight values can be determined are the cases of sulfur, titanium, iron, selenium, antimony, tellurium, europium, and iridium. In some cases, the data involved may have been reviewed after the Hamburg meeting.

- Research carried out under the auspices of the U.S. Department of Energy, Contract No. DE-ACO2-76CH00016. 


\section{DISCLAIMER}

This report was prepared as an account of work sponsored by an agency of the United States Government. Neither the United States Government nor any agency thereof, nor any of their employees, makes any warranty, express or implied, or assumes any legal liability or responsibility for the accuracy, completeness, or usefulness of any information, apparatus, product, or process disclosed, or represents that its use would not infringe privately owned rights. Reference herein to any specific commercial product, process, or service by trade name, trademark, manufacturer, or otherwise does not necessarily constitute or imply its endorsement, recommendation, or favoring by the United States Government or any agency thereof. The views and opinions of authors expressed herein do not necessarily state or reflect those of the United States Government or any agency thereof. 


\section{DISCLAIMER}

Portions of this document may be illegible in electronic image products. Images are produced from the best available original document. 
91Aakl S.Aalto,J.H.Black,L.B.B.Johansson, R.S.Booth, Astron.Astrophys 249,323 (1991)

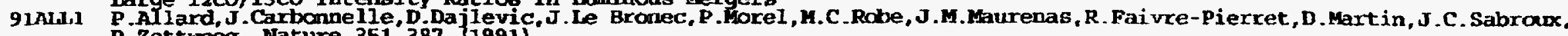
P. Zettwoog, Nature 351,387 (1991)

Haisions af $\mathrm{CO} 2$ from Hount Etria

91 Amal H.Amakawa,J.Ingri, A. Lasuda, H.Shimizu, Earth Plant.Sci.lett, 105,554 (1991)

Isotopic Compositions of Ce, Fd and Sr in Ferromanganese Nodules frcm the pacific and atlantic Oceans, the Baltic

91 AN1 J.B.Anderson, D.E.Reid.M.Taviani, Hem.SOc.Geol.It. 46,561 (1991)

Compositionai and Geochemical Characteristics of Recent Biogenic Cartomates from the Ross Sea (Antarctica)

$91 B I D 1$ R.R.Bidigare, M.C.Kennicutt II,W.I. Keeney-Kermicute.S.A. Macko, Anal. Chem. 63.130 (1991) Isolatica and Purification of Chlorophylls $a$ and $b$ for the Determinatica of 'stable Carbon and Nitrogen Isotope

T1BIR1 Compositions

Isotopes in Ccments: Impi ications from $\mathrm{Cr}$ in Carbonaceous Chondrites

H.I.Bird, A.R.Chivas, W.S. Pyfe.

91BJO1 M.BjoroY,K.Hall,P.GiliYco,J.Jumeau, Chem.Ceol 93,13 (1991)

Caxbon Isotcpe Variaticns in $\mathbf{n}$-Alkanes and Iscorenoids of mole 0 ils

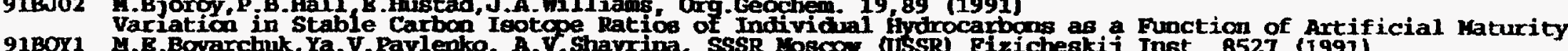

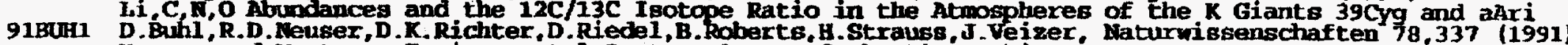

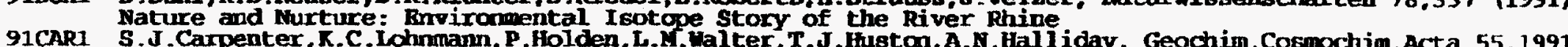

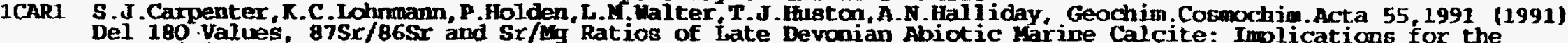

Composition of Ancient Seamater

91CBR1 T.E.Cerling,D.Kip Solonon,J.Quade.J.R.Bonman, Geochin.Cosmochim.Acta 55,3403 (1991)

910 al T. the Isotopic Composition of Carbon in Soil Carbon Dicocide

91Cra2 The Atomic theight of Buropium

91CLA1 The Atamic Weight of Indium Gelogy 8,232 (1991)

91C1A2 R.F.Clayton,T.R.Mactionation During Ratural Gag Generation from Rerogen 2317 (1991)

9101A3 Oxygen fsotipe Studies of Ondinary Chondrites

$9100 p 1$ Effect of Haturity on Carbon Isotope Ratios of Oils and condensates 9100 1 R.f.Corfield, J.R.Cartildge, I. Premoli-silva, R.A.Housley. Terca Research 414 (1991) Qxygen and Carbon Isotope Stratigraphy of the palaeogene and Cretaceous limestones in the Bottaccione Gorge an

91CRA1 P.Crane,D.J.Hegł, D.L. Tambert; Astrgofys.J. 378,181 (1991)

91CRR1 R.A.Creaser,D.A.Papanastassiov,G.J. Wasserburg, Geochim.Cosmochim.Acta 55, 398 (1991)

910 1 C.De Bergh, B-Bezard, T. Omen, B.Crisp,J.-p.Haillard, B.L.Iutz, Science 251, 547 (1991)

10 Deuterium con Verus. Observations Trom Barth

91 DBB1 M.Deb, J.Hoefs, A. Baumarm, Geochim.Cosmochim.Acta 55, 303 (1991)

910EI 1 P.Deines, J. W.Harrig,D.M.Robinson, J.J.Gumey,S.R.Shee, Geochim_Cosmochim, Acta 55,515 (1991)

Carbon and Oxygen Isotope Variations in Diariond and Graphite Bclogites from orapa. Botswana, and the Nitrogen

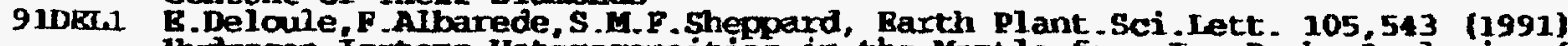
9101C1 Hydrogen Isctope Heterogeneities in the Mantle from Ion Probe Analysis of Amphiboles from oltramafic Rocks

Disequilibrium Caxbm and Oxygen Isotope Variations in Natural Calcite

9100 H.Domes, P.D.Kempton,D.Briot.R.S.Hamon, A.F.Leyreloup, Earth P1ant.Sci. Lett. 102 342 (1991)

$\mathrm{Pb}$ and $\mathrm{O}$ Isotope Systematics in Gramilite Facies Xenoil ths, French Massif Centrai: Implications for Crustal

91 FaU1 K.Faure, C.Harris, Precambrian Res. 52, 301 (1991)

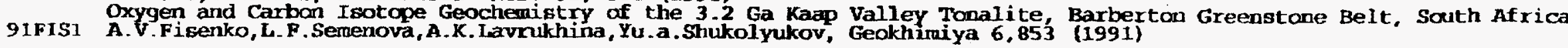

91ARLOI

TARLO2

91AnI02

9IALLOS

9LALAO1

$91 \mathrm{ALAO} 2$

g1Auno 3

9 91ANDO1

$91 \mathrm{BI001}$

9181001

$91 \mathrm{BIDO} 3$

$91 \mathrm{BIRO}$

giBIRO2

91 BLRO 3

91 BIR04

9 IB.T001

$91 \mathrm{BJO02}$

$91 \mathrm{BJ003}$

$91 B 004$

91BOYO1

$91 B O Y 02$

918uHo1

9181402

91 Caro1

9 ICAR02

91 CARO 3

91 CGR01

9 CRRO2

9107A01

91 ano2

1 Crad

91 CLAOI

91 Cla 22

$91 C 1 \mathrm{AO} 3$

91 CIA04

$91 C A 205$

1CHAO6

91 COPOI

9100002

$9100 R 01$

$9100 \mathrm{R} 02$

91 CaRo3

91CRAO1

91 CRAO2

$91 \mathrm{CrEO}$

$91 \mathrm{CREO2}$

$910 \mathrm{E} 01$

$910 \mathrm{BB} 01$

$910 \mathrm{DBO} 2$

$91 D E I 01$

$910 R I 02$

91DBIO 3

$910 E L 01$

$910 \mathrm{KLO} 2$

$910 T C 01$

9100 w01

$91 \mathrm{DOH} 02$

9100103

91 FADO 1

91 FISO1 
910HI1 T.Ohi zumi, N.Fukuzaki, N.Moxiyama, Y.Unushiyama, M.Kusakabe, Chem.Soc.Japan 5.675 (1991) Source of sulfux in the Atmospheric Deposits in View of Sulfur Isotopic Variaticns - A Case Study in Ni igata

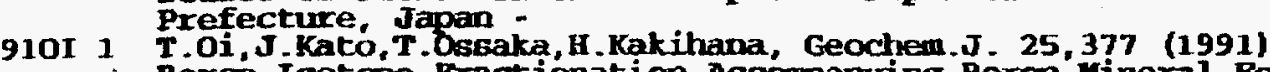
Boran Isotope Practionation Acoonpanying Boron Mineral Formation from Aqueous Boric Acid-Sodium Hydroxide Solucions at 25 Degrees $C$

910ZI1 M.Ozima, S.Zashu,K.Tomura, Y.Matsuhisa, Nature 351.472 (1991)

Constraints from Noble-Gas Contents on the Oxigin of Carbonado Diamonds

$910 z 12$ M.Ozima,S.Zasim, Barth and planet.Sci.Lett. 105,13 (1991) M.R.Palmer, Chem.Geol. 94,111 (1991)

Boran Isotope Systematics of Hycothermal Fluids and Toumal ines: $A$ Synthesi

91 PEAl D.G.Pearsom,G.R.Davis,P.H.Mixom,P.B.Greenwood, D.P. Hattey, Barth and planetary Sci.Lett. 102, 289 (1991) Oxygen Isotope Bvidence for the Origin of Pyroucenites in the Beni Bousera Peridotite Massif. North Horocco: Derivation from Subducted

91 PEII J.R.Petit,J.W.C.White,N.W.Young,J.JouzeI,Y.S.Korotkevich, J.Geophys.Res. 96,D3,5113 (1991)

91PIE Deuteriug kxcess in Recent Antarcte snom

Oxyoen and Carbon Stable Isotope Tracers of the vater Wasses in the Central Brazil Basin

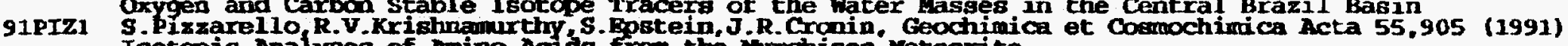

91P001 R.P.R.Poorter,J.C.Varekamp, R.J. Poreda, M.J.van Bergen, R. Kreulen, Geochim.Cosmochim.Acta 55, 3795 (1991)

g1Pow M.D.Powel 1.T.K.Kyser. Chem.Geol. 94.55 (1991)

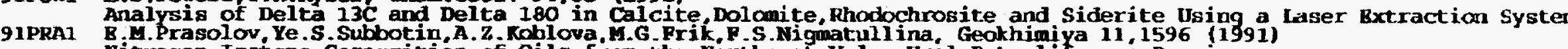

91 PRA1 Bitrogen-Isotope Composition of Oils from the Northeast Volga-Ural Petroliferous province

91pRT1 T. J Primer, H.Shaw, Karine and Petrol Goology, 8,225 (1991) Variations the Delta $D$ and Delta 180 Compositions of Illite-smectites in a Partly Overpressured Tertiary

91RAD1 G.A.Rau,T.Takahashi,D.J.Des Maraig,C-W.Sullivan, J.Geophys.Res. 90,15,131 (1991)

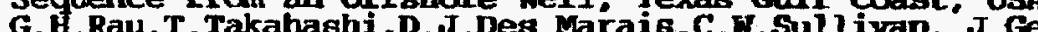

91 REI1 L.C.Reisberg, C.J.Allegre,J.-H.Luck, Barth plant.Sci.Lett. 105, 196 (1991)

91RIB1 T.Rieley,R.J.Collier,D.H.Jomes,G.Eglinton, P.A.Rakin,A.B.Pallick, Sature 352,425 (1991)

Sources of Sedimentary lipids Deduced from stable Carbon-Isotope Analyses of Individual Compounds

91RnM C.P.Rinsland,H.R.Gunson.J.C.Fogter,R.A.Toth.C.B. Parmer.R.Zander, J.Geophyg. Res. 96, I057 (1991) Stratospheric profiles of Heavy Water vapor Isotopes and CH3D from Analys is of the ATMOS Spacelab 3 Infrared B.W.Robinson, A.V.Hiriner,G.I.Lyco, Chem.Geol, 86, 295 (1991) Stahle Carbon and Sulfur Isotope Distributions of Crude Oil and Source Rock Constituents from Burgan and

91 SACl W.M.Sackett, Marine Chem, 34.153 (1991)

A History of the Delta $13 \mathrm{C}$ Composition of Odeanic Plankton

L.J.Sage, R. Nauexsherger, C, Henkel, Astron.Astrophys 249 , 1 (1991)

Bxtragalactic 180/170 Ratios and Stax Pormation: High-vass Stars Preferred in Starburst Systems S. Sakata, Geochim. Cosmoctim. Acta 55,1395 (1991)

Carbon Isotope Geochemistry of Natural Gases from Green Tuff Basin, Japan A. Sarkar, S. K. Bhattacharya, W. H. Mohabey, Geology 19,1068 (1991)

Stable-Isotope Analyses of Dinosaur Bggshel Is: Palecenvironmental Implications E.-D.Schu ze, G. Gebauer, W.Schulze,J.S.Pate, Decologia 87, 240 (1991)

$91 \mathrm{SC}$ The dtilization of Vitrogen from Insect Capture pur pifferent

91SIG1

91SIL1 Geochemical Constraints on Source Region of Cretaceous/Tertiary impact Gradel, S. J.A.Silfer,M.H.Bngel,S.A.Hacko, E.J.Jumeau, Anal.Chem. 63,370 (1991) Stable Carbon Isotope Aralysis of Amino Acid Enanticmers by conventional Isotope Ratio Mass Spectrometry and

$915 M 1$ Combined Gas Chromatography I Gotope Ratio Mass Spectrometry Coim. Acta 248, 229 (1991 Measurement of Boron Concentration and Isotope Ratios in Biological Samples by Inductively Coupled plasma Mass Spectrometry with Direct Injection Nebulization

91 SMI 2 B.N.Smith, H.zieglex.J.Lipp. Naturwissenschaften 78, 358 (1991)

9150 Isotopic Evidence for Nesophyll Reduction in Zea Mays, an NApp-Malic Bnzyme Plant

GEOSECS Pacilic and Indian Ocean 32 Si profiles

$915 T 1$ P.Stille,R.H.Steiger. Contrib.Mineral petrol. 107, 273 (1991)

Hé Isotope Systematićs in Granitoids from the Central and Southern Alps

910 HI 01 $910 \mathrm{HIO}$ $9104 \pi 03$ $910 \mathrm{O} 01$ 910102 910103 9102101 9102102 $910 z 103$ $910 z 104$ 91PAL01 $91 \mathrm{~g} A 02$ 91 PRAO 1 91 PaAO gIPkAO 91 PETO 1 $91 \mathrm{pLT}$ $91 P I B 01$ 91 PIEO2 $91 P 1 z 01$ $91 P 1202$ 91 0002 91Fon 91 PONO1 31 PONO2 91 PRAO1 91 PRAO2 2 91PRIOI 91PRI02 g1PRTO3 g1RADO1 gIRAUO2 9lRk101 gikn 91 IRO2 91RINOI IRINO2 g1R INNO 3 $91 \mathrm{RCBO} 1$ $91 \mathrm{ROBO} 2$ grano 1 91 SACO1 91 SACO2

91 SAKO1

91 SAG02

gisak01

9ISAR0I

9ISAR02

91 SCHO 1

1 SCHO2

9151601

9151602

$915 I L 01$

$915 I 102$

$915 n 03$

91 SM 01

91 SMI 02

915MI04

915MI04

91 SOmol.

$91 \mathrm{SOM} 02$

15TI 
$915 T 01$ J.Stone, I.D.Hutcheon, S.Epstein,G.J.Hasserburg, Earth Planet.Sci.Iett. 107,570. (1991)

Correlated Si Isotope Ancmalies and Iarge $13 \mathrm{C}$ Enrichments in a Family of Bxotic Sic Grains

91sunl N.B.SuntzefE, V.V.Smith, Astrophy.J. 381,160 (1991)

Carbon Ifotopic Abumdances in Giant Starts in the CN-Bimodal Globulax Cluster NGC 6752 and MA

915 ta1 P.K.Swart, S.J.Burns, d.J.Leder, Chem.Geology 86,89 (1991)

Fractionation of the stable Isotopes of Oxygen and Carban in Carbon Dioxide During the Reaction of Calcite with Phosphoric Acid as a Function of Temperatuxe and Technique

91SYN Ye.D.Syngayevskiry, Geokhimiya 12,1791 (1991)

MSA-7 and ISA-8 Standard Speciments for Carbon and Oxygen Isotope Comsositions

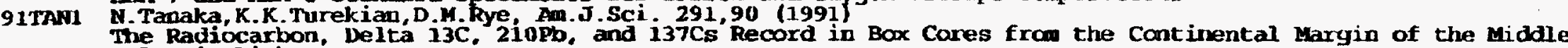
At lantic

91 Tave N.Tanaka, D. H. Rye, Nature 353,707 (1991)

917wI1 M.H.Thiemens, T.Jackson, R. Hawergberger, B.Schueler, J.Hartco, Geophys. Pes. Lett. 18, 669 (1991)

11 Orygen Isotope Fractionation in stratospheric co

91 TII2 H. Thirlwall. Chem,Geology 94,13 (1991)

High-Precision Nulticollectar Isotopic Analysis of Low levels of Na as oxide

91 Top1 Z. Tqu, G.Ostiund, I.Pope,C.Grail, Deep-Sea Res. 38, S747 (1991)

Relitum Isotgpes, Becn and Tritiun in the Black Sea: A Compaxison with the 1975 Observations N. Torigove, I. Shima, Lass spectrosc. 39, 1 (1991)

Steprige Dissolution and Grain Size Separation for Obtaining the Rb-Sr Internal Isochran: Application to Bnstatite Chandrite

910kD1 S.Ueda,T. Yokhinari, B.Wada, N.Ogura, Chem.Soc.Japan 5,448 (1991)

Nitrogen Stable Isotope Ratio of 20 in Groundwater: A Possibie Tool to Determine the Source Wechanisms

S. Deda.N. Ogura, E. Wada, Geophys. Res.Iett. 18,1449 (1991)

910 SD1 Ritrogen Stable Isotope Ratio of Groundwater R20

Pactors for Oxygen Isotcpe Bquilibrium Fractionation Between Aqueous and Gaseous Co2, Carbonic Acid, Bicarbonate, Carbonate, and tater (19 Degree C)

91 all S.Valkiers,p.De Bievre,G.Ienaers, H.S.Peiser, CBRM Hass Spectrom. GB/R/us/05/91

91 VA.2 Silicon Reference Haterials Certified for Isotope Abundances. Stand.Techmol. 96,617 (1991)

91valu Silicon Reference Yaterials Cerified for Isotope Abundances

Ion Wicroprobe Analysis of Oxygen Isotope Ratios in Gramiite Facies Magnetites: Diffusive Bxchange as a Guide to

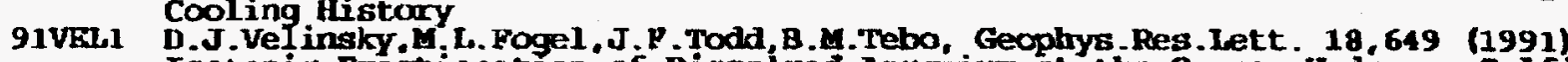

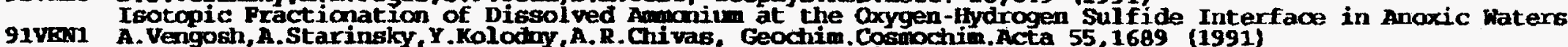

Baran Isotope Geochemistry as Tracer for the Bvolution of Brines and Associated Hot Springs fram the Dead Sea.

91 ver Israel Yu.A. Shukolyukơ, Ceokhimiya 6,840 (1991)

Inert-Gas Isotopes as Indicators of Geotectcnic Processes: Variations in Inert-Gas Contents and Isotope Ratios

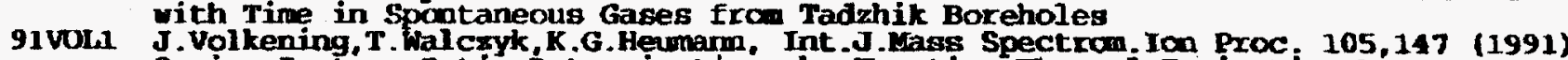

91 o.2 Osmium Isotope Ratio beteminations by Negative Thermai Icnization Mass Spectronetry

91 on.3 Determination of Radium Isotope Ratios and Abundances in Geologic Samples by Thermal Ionization Mass Spectrometry

9160Y1 Tungsten Isotope Ratio Determinations by Negative Themal Ionization toss Spectrometry

91wat. Chemical and Carbon-Isotope pluctuations in Free Gases (Gas JetG) in the (Whibiny

91HALI C.J.Waldie, R.C.Jowett, H.S.Swinden, At lantic Geology 27, 1 (1991) 91war, The Crescent Iake Coppex Deposit, Central Nenfoundand: Deep Ievels of a Volcanogenic Hydrothermal System Re-os Isotope Systematics of $\mathrm{Ni}$-Cu Sulfide Ores. Suóbury Igneous Compiex. Ontario: Bvidence for a Major Crustal

91 mal 3 T.bal cent

T. Walczyk, B.H.Hebeda, K.G. Heunann, Fresenius J.Anal.Chem. 341,537 (1991)

Osmium Isotope Ratio Measurentents by Neqative Thermal Tomization Nass Spectrometry (KrT-MS) Improvement in

91 kAs1 Precivion and Enchancenent in Bmission by Int roducing Oxygen or Freons 

uass Spectrometry

92CR01 D.E.Crowe.J. T.Valley, Chem.Geology 101,63 (1992)

laser Hicroprobe Study of Sulfur Isotope Variation in a Sea-Floor Fydrothermal Spire, Axial Seamount, Juan de Puca

92Dan1 Didge, Eastern Pacific. Chem.Geology 86, 75 (1992)

920 ar2 Oxygen Isotopes in hiving Nammal's Bone Phosphate: Further Results

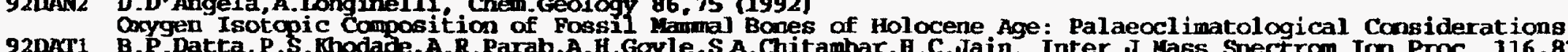

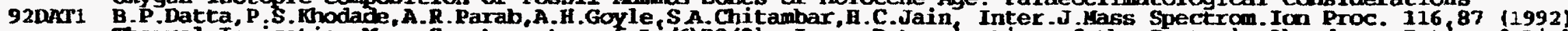

920ral Thermal Ionigation Lass Spectrometry of $w(2)$ BO(2) + Ions: Determination of the Isotcpic Abudance Ratio of hithium

Seawater Sr Isotope variation Over the past $300 \mathrm{ky}$ and Influence of Global climate Cycle

92DIE1 M.Dietze1, E. Usdowski.J.Hoefs. Apol. Geochem. 7,177 (1992)

92 CuB1 J.C.Duboi a, Retali J Cesario, Inter.J.Lass Spectrom. Ion Proc. 120,163 (1992)

92RAR1

Isotopic Anaiysis of Rane Earth Elements by Total Vaporization of Samples in Thermal Ionization Mass Spectrometry

P.A.Bakin, A.B.Pallick, J.Gerc, Chem, Ceology 301, 71 (1992)

Some Instrumental Effects in the Determination of Stable Caxton Isotope Ratios by Gas Chromatography-Isotope

92EAS1 C.J.Bastoe, J.M.Guilbert, Geochim.Cosmochim.Acta. 56.1247 (1992)

92EIP1 Stable Chiorime Isotopes in Hydxothermal Prccesses:

92kSA1 In Situ Oxygen Isotope hialysis of peldgpar and guarz by wd: yag Iaser Micrcprobe

92EAR Magnesium I Botcoe practionation in Ienar soing

92EARI K.A.Farley,J.H. Fatland, H.Craig, Barth plant Sci. lett 111, 183 (1992)

92FRI1 Binary Hixing of Bnriched and Undegassed (Primitive ?) Hantle Conponents (He, Sr, Hd, Pb) in Samoan Lavas

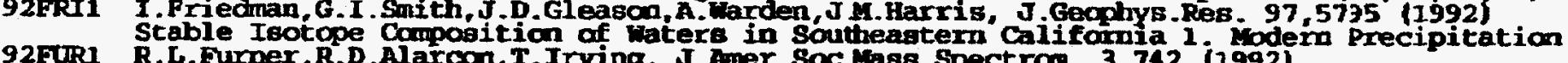

Quadrupole-Based Kass Spectrometric Bvaiuation of Isotope Ratios of Carbon Dioxide in Bxpired Air from Hice and

Uen Following the Administration of 13C-Lethyl Hethionine

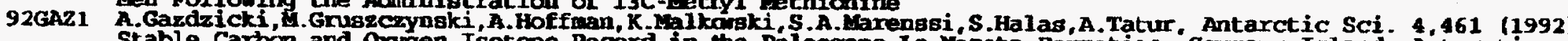

92GKB1 Stable Carbcm and Oxygen Isotope Record in the Paleogene Ia Eeseta Pormation, Seymour Island, Antarctica

92GKB1 G.Gebauer. Isotopeppraxis 28,68 (11992)

92GIB1 Deita 15N-Werte AIs Hittel zur Analyse der sickstoffemahnmg Bei Insektivoren Pflanzen

The Isotopic Composition of Cosic-Ray B.C. ane, W. R. Webber, Astrophys.J. 391, Is9 (1992)

92GII I.Gilmour,S.S.Russeli,J.W.Amden,H.R.Iee,I.A. and O: Bvidence for an Overaimdance of 180

92GRA1 Terrestrial Carbom and Nitrogen Isotopic Ratiog Ircm Cretaceous-Tertiary Boundary Nanodianonds

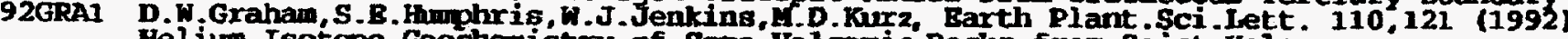

92GRA2 helium Isotgpe Geochemistry of Some Volcanic Rocks from Saint Helena

(1992)

92GRA3 C.M.Graham,J.W.Valley, Chem.Geology 101.169 (1992)

92 Han

92HEal N.G.Henming.G.N.Hanson, Geochum.Cosmochim.Acta 56,537 (1992)

924 Boran Isotopic Composition and Concentration in Modern Marine Carbonate

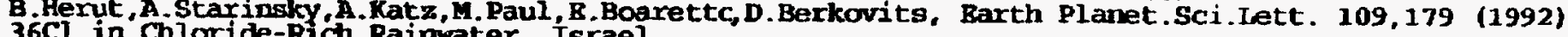

$924 \mathrm{r} 2$ Romater, Israel

2HBR2 R.L.Hervig, P. Williams, R.M.Thomas,S.M.Schauer, I.M.Steele. Int.J.Mass Spectrom.Ion Proc. 120,45 (1992)

92HoL1 H.Holail. H.Rashed. Oxyen Isotopes in Insulators by Secondary Ion Hass Spectrometry

Stable Isotopic Composition of Carbonate-Cerented Recent Beachrock Along the wediterranean and the Red Sea

92ION1 D.A. Ionov, J.Hoefs, K.H.Wedepohl,W.Wiechert, Gntent and Isotopic Composition of Sulphur in Dltramafic Xecoliths

92Tshi Irom Central Asia

T.Ishikawa, E. Nakamura, Geochim.Cosmochim. Acta 56,1633 (1992)

921Tu1 Borcn Isotope Geochemistry of the Oceanic Crust from DSDP/ODp Hole 504B

Identification of 2360 in Cormercially Available Uranium Compounds by Alpha Paxticle Spectrometry 
921 U02 J.L.Iturbe J.Radioanal Mucl . Chem.Lett. 166,263 (1992)

co $2340 / 2380$ and $2350 / 2380$ Rafios from Commercially Avialable Dranium Compoumds by Alpha-Spectrometry 92 Iruo

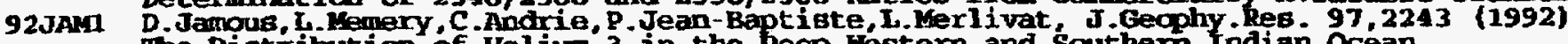

$92 J 0 R 1$ The Distribution of Helium 3 in the beep Whas

Methane-Derived Carbonate Cementation of Marine Sediments from Kattegat, Denmark: Geochemical and Geological Bvidence

92KAH1 C.Kahane, J.Cernicharo, J.Gomez-Gonzalez,M.Guelin, Astron.Astrophys. 256, 235 (1992)

Isotopic Abundances in Carbon-Rich Circumstellar Envelopes: A Further Iteration on the Oxygen Isotope Pruzle

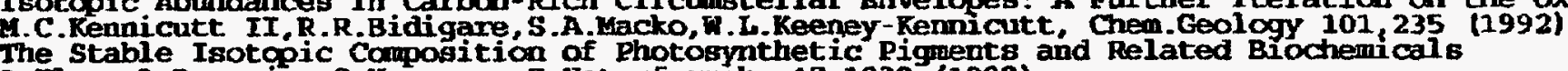

92 Kur1 A. Kem,A.Banerjee, S.Hoernes, Z. Naturfarsch. 47,1232 (1992)

Further study of Intersectorial Isotope Fract ionation in Quarts

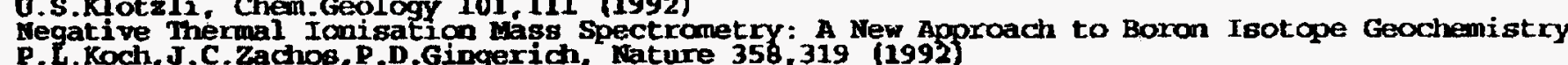

$92 \mathrm{Krocl}$

92Kun

Correlation between Isotope Records in warine and Continental Carbon Reservoirs Near the Palaeocene/Bocene Boundary Purther Measurements on Isotopic Anomalies of 196tg/202kg Ratio in Sume of Acid Insoluble Residues of Sikhote Alin and other Iron Heteorites

92kJRI P.K.Kuroda, Geochem.J. 26, 1 (1992)

pivtonium-244 in the Barly solar Systen and the Pre-Fermi hatural Reactor

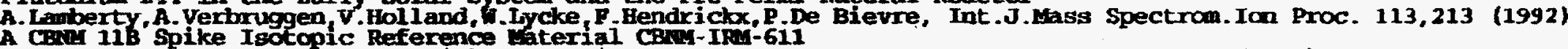

92LALR A.Lamberty, A. Yerbruggen, P.Hendricikx, P.De Bievre, Int.J.Hass Spectrom.Ion Proc. 113,223 (1992)

92LAVI A.K.Iavulhina Geothipic Reference Hate

92131 The Primary Material of the Protoplanetary rebula: Isotope Composition of $H, C, N$. and $O$

Carbonate Dissolutión Fluctuationg in the Western squatorial Pacific During the Iate Quaternary

921 Ba1 S.W.Ieavitt, Naturwiseensch. 79,178 (1992)

921 ma2 Aititudinal Differences in Delta $13 \mathrm{C}$ of Bristlecone pine Tree Rings

92LEA2 S.H.Leavitt,R.M.Kalin. Radiocarbon 34,792 (1992) 50,000 Years

92Ins1 A Bew Tree-king Width. Belta 13C and 14C Investigatiom of the Two Creeks site

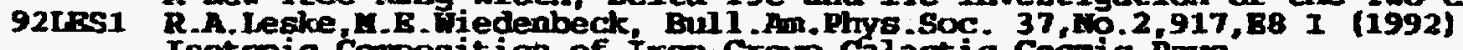

$92 \mathrm{HCl}$ Isotcoic Composition of Iron-Group Calactic Costac Rays

9210 1 Oxygen Isotgpe Fractionation between Grossular-Spessartine Gamet and hater: An Experimentai Investigation

92trac1 A. Dackensen, U. Uhmmann, of Isotcoe Ratios of Wolybdenum in Some Terrestrial wolybdenites

Middle Bocene Through Rarly Oligocene Climate History and Paleoceanography in the Southern ocean: Stable Oaxgen and

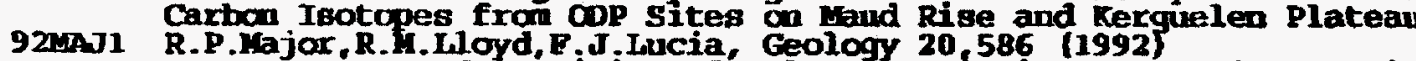

Oxygen Isotgpe Composition of Holocene Dolomite Formed in a Huid Hypersal ine Setting

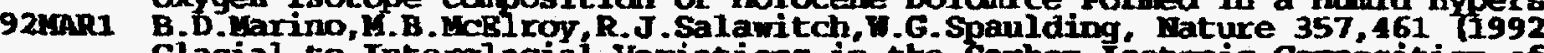

921AR2 Glacial-to-Interglacial Variations in the Carbon Igotopic Composition of Atmogpheric co (2)

92MAR2 B.Harty,R.K.O Nions, B.R. Oxburgh,D.Kartel,S.Lombardi, Tectonophysics 206,71 (1992)

$92 \mathrm{maR2}$ C.S.Martens.C.A.Kelley,J.P.Chanton,W.J.Showers, J.Geophys.Res. $97,16.701$ (1992)

Carhon and fydrogen Isotopic Characterization of jethane from wetlands and Lakes of the Yukon-Kubkokwin Delta,

Westem Alaska . T.Tyson, J.Thoupson, D. Hattey, Marine Geolog. 105.51 (1992)

$921 \mathrm{Cal}$ J.M.McArthur, R.V.TYEon, J.Thompson, D. Hattey, Marine Geolog 105,51 (1992)

924rcsi Barly Diagenesig of Marine Organic Matter: Alteration of the Cartbon

Variability of the Delata 13C of Dissolved Inorganic Cadbon at a site in the North Pacific ocean

P.A.teyer. Chem.Geology 101,283 (1992)

Changes in Organic Carbon Stable Isotope Ratios Across the k/T Boumdary: Glabal or local Control ?

92 MIII H.Minagana, Appl. Ceochem 7145 (1992)

Reconstructuon of Human Diet from Delta 13c and Delta 158 in Contemporary Japanese Hair: A Stochastic Method for Reconstructuon of Human Diet from Delta $13 \mathrm{C}$ and Delta $15 \mathrm{in}$ in Cont

92ms1 Kstimating Multi-Solurce Contribution by Double Isotopic

Ng Isotopic Compositions of Stary Spherules from Deep-Sea Sediments

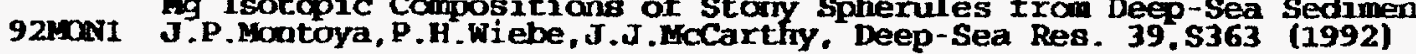


92MOZ1

$9240 Z 2$

92ख⿰亻⿱

92NAKa

$920 \mathrm{r}$

920RT1

92PALI

92PAL2

92PAR1

92PEGI

92PBG2

92PLA1

92POR1

92 POR2

$92 \mathrm{FOR} 3$

92PORA

92PCR5

920LAI

920001

92RAO1

92REC1

92REI 1

92R081

92Raxa

92rort

92ROZ1

92R001

92SAI 1

92 SAK1

92SAN1 ratural Abundance of $15 \mathrm{~N}$ in Particulate Nitrogen and Zooplankton in the Gulf Stream Region and ham-Cone Ring 86A P.S.Nozley, W.W.Carotherg, J.Sedimentary Petrology 62, 681 (1992)

Blemental and Isotopic Composition of Siderite in the Ruparuk Pormation, Alaska: Bffect of Microbial Activity and hater/sediment Interaction on Early Pore-Water Chemistry

S. Hozley. P. Wersin. Geology 20,817 (1992)

Isotopic Camposition of Siderite as an Indicator of Depositional firvironment

Ph. Muchez, C. Peeters. H.Viaene, E. Reppens, Chem.Geology 102 , 119 (1992)

Stable Isotopic Composition of an Bvaporite Dissolution Breccia in the Lower Visean Limestones of SE Belgium

Chakara, T . Shikawa, J -L.Birck, C.J.Alegre, Chem.Geol. 94.193 (1992)

T.oise Borcon Isotopic Analysis of Katural Pock Samples using a Boron-Kannitol Jomplex

Prac, ogino, H.hosoe, h. Kakihana, Separation Sci.Technol 27,631 (1992)

G.S.Orton, J.H.LacY.J.M.Achterman, P. Parmar, W. B.B1ass, ICARCus 100,541 (1992)

Thermal Spect rosccpy of Neptume: The Stratospheric Temperature Hydrocarbon Abundances, and Isotqpic Ratios

Thorium Isotope Ratio Neasurements at High Abumbance' Sensitivity Using a vg $54-30$ (R), An Bnergy-Filtered Thexmal Ionization Jass Spectrometer

M.R.Palmer, D.Iondon G.B. vorgan VI.H.A. Babb, Chem.Geology 101,123 (1992)

Bxperimental Detemination of Fractionation of $11 B / 10 B$ between Tourmaline ard Aqueous Vapor: A Temperature - and ressure-Dependent Isotopic System

Isotope Ratio Masurements of Iron, Bromine and Selenium in Aqueous Solutions by Helium Microvave-Induced plasma Nass Spectrometry

.J.Pegram, C. -J.Allegre, Earth plant.Sci.Lett. 111.59 (1992)

Ssmiun Isotopic Compositions from Oceanic Bacalts

M.J.Pegram, S.Kri shnaswami, G.E.Ravizza, K.K.Turekian, Barth Planet.Sci.Iett. 113,569 (1992)

The Record of Sea water 1870s/1860s variation through the Cemonoic

A.d.Plater, Y. I vanovich R. B Dugdale. Apol _Gecchem. 7, 101 (1992)

Uranivm Series Disequilibrium in River Sediments and Haters: The Significance of Ancmalous Activity Ratios

R.J.Poreda, T.R.Cerling, Geophys .Res.1ett, 19,1863 (1992)

Cosogenic Neon in Recent Lavas from the Western United States

Rare Gases in Samoan X́ Xenoliths

R.J.Poreda, H.Craig, Earth Planet. Sci.Lett. 113,487 (1992)

He and Sr Isotopes in the Laa Basin wontle: Depleted and Primitive Mantle Comonents

R.J.Poreda,H.Craig, S.Amorsscn,J.A.nelhan, Geochim.Cosmochin.Acta 56,4221 (1992)

Helium Igotgpes in Icelandic Geothermal Systems: I. 3Fe, Gas Chemistry, and 13C Relations

R.Poreda, S.Arnorsson Geochim.Cosmochim. Acta 56,4229 (1992)

Helotopes in Icelandic Geothermal Systems: II. Helium-heat Relationships

. Qian, M.H. Fngel, S.A. Macko, Chem_Geology 101, 201 (1992)

Stable Isotcpe Fracticnation of Biomonomers During Protokerogen Pormaticm

P.D.Quay, B.Tilbrook, C.S.Wong, Science 256,74 (1992)

Dceanic tptake of Fossil Fuel CO(2) Carban-13 Bvidence

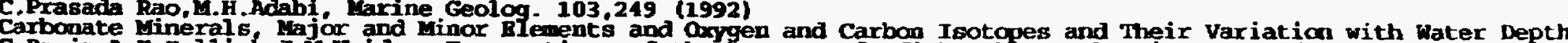

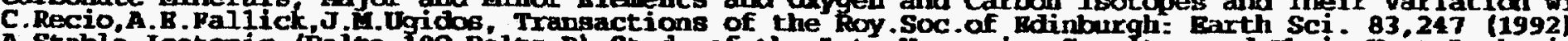

A Stable Isotopic (peita 180, Delta D) Study of the Late-Hercynian Granites and theix Host-Rocks in the Central

Iberian vassif (Spain)

Oxgen and Carbon Isotope Pattems in the Dicker Willem Carbonatite Camplex, Southern Namibia

P.Robert, A.Rejou-Miche1, 4 . Javoy, Earth plant.Sci. Iett. 108,1 (1992)

oxygen Isotople homogeneity of the Baxth: New Bvidence

C. komanek, B.L.Grostman, J.W.Morse. Geochim.Cosochim.Acta 56,479 (1992)

Carbon Isotopic Practicmation in Synthetic Aragoaite and Calcite: Rffects of Tenperature and Precipitation Rate MiRotaru,J.L.Birck,C.J.Allegre, Nature 358,465 (1992)

Clues to Rarly Solar System History from Chromium Isotopes in Caxbonaceous Chondrites

Rel at inski, L.Axaguas-Araguas, R.Gonfiantini, Science 258,981 (1992)

Relation between Iong-Term Trends of Oxygen-18 Isotope Composition of precipitation and c1imate

4.i:Ruducki, H.Blderfield, Barth planet.sci.Iett. 113, 307 (1992)

Helium, Radon and Manganese at the Th and Snakepit Hydrothermal Vent. Fields, 26 Degrees and 23 Degrees $N$,

Mid-At lantic Ridge

T.Saino, Deep-Sea Res. 39. S347 (1992)

1 5N and 13C Natural Abundance in Suspendezd Particulate Organic Matter frcm a Kuroshio Warm-Core Ring

M.Sakamuto, Y. Sario, Hakita, Geochem J. 26,189 (1992

A. 
Rapid Method for Determination of the Isotopic Compositica of Dranium Samples by Alpha Spectrometry (1992) Oxygen Isotcpe Exchange in Tro-Layer Hocel of Oceenic Crust H.Scheele,J.Hoefs, Contrib.Mineral Petrol 112,35 (1992) and Stable $\mathbf{P b}$ Isotopes

$92 S H 1$ A.Shimoyam,0. Matsubaya, Chem.Iett. P.1205 (1992)

$925 n 1$ Jarbon Isotope Compositions of Graphite and Carbonate in $3.8 \times 10$ (9) Years 0ld Isua Rockss

Kinetic Practionation of Stable Carbon and Atrogen Isotopes During Peptide Bond Hydrolysio: Experimental Bvidence and Geochemical Implications

925rI1 G.I.Smith, I.Friedman, J.D.Gleason, A. Larden, J.Gecohys.Res. 97,5813 (1992)

Stable Isotope Composition of Naters in Southeastem California: 2. Groundwaters and Their Relation to todern Precipitation

9250N1 T.Sowers, M. Bender, D.Raynaud, Y.S.Korotkevich, J.Geophys.Res. 97, 15,683 (1992)

Delta $15 \mathrm{M}$ of M(2) in Air Trapped in POlar Ice: A Tracer of Gas Transport in the Firn and Possible Constraint on Ice Age-Gas Age Differences

$9250 G 1$ N.Sugiura, K. Hashixume, Farth planet.Sci.Iett. 111,441 (1992)

92TAY 1 Nitrogen Isotope Ancmalies in Primitive Ordinary Chondrites Chem Geology 94,215 (1992)

Stable Isotcoe Compositions of Tourinai ines frcu Granites and Related fyotrothermal Rocks of the Karagwe-Ankolean Belt, Noxthwest Tanzania

92 Tar2 P.D.P.Taylor,R.Maeck,P.De Bievre, Inter.J.Lase Spectrom.Ion Proc. 121,111 (1992)

92Tupl Determination of the Aboolute Isotopic Composition and Atomic Neight of a Reference Sarmie of Datural Iron

920rrer Helium(heat Ratios and Deposition Temperatures of Suphides from the Ocean Floor

92vah Oxygen and Sulphw Isotgoe Compositions as Indicat

92var Oxygen Isotope weasurement of Ragnetites

Stable Isotope Byidence for. Bny ry of Sewage-Derived Organic Naterial Into a Deep-Sea Eood Web

92VkN A.Vengosh, A.Starinsky, Y. Kolodin, A.R.Chivas, R. Raab, Geology 20.799 (1992)

Boran Isotope Variations During Fractional Braporation af Sea Water: Hew Constraints on the Warine vs. Normarine

92 wow D.ven Grafenstein,H.Brlenkeusex, J.Muller, A.Keimann-Bi gemam, Daturwis6ensch. 79,145 (1992)

921 ACl Oxygen Isotope Pecords of Benthic Ostracods in Bavaxian Iake Sediments Megative Thermal Ionization isss Spectrometry of Lain Group Rlements part 2.* 6th Group: Sulfux, Selenium and Tellurium

925aD1 M.A.Wadleigh, J. Veizer, Geochim. Cosmochim.Acta 56,431 (1992) $180 / 160$ and $13 \mathrm{C} / 12 \mathrm{C}$ in Lower Paleosoic Articulate Brachipods: Implications for the Isotopic Composition of

92wILl Reawater High Th/U Ratios in Subcont inental Lithospheric Hantie: Hass Spectrometric Heasurement of Th Isotopes in Gaussberg Lawpoites

92 W.2 T.L.Wilson, R.Maversberger, N.D.Iangex,A.E.Glassgold,R.W.Wilson, Astron.Astrophys. 262,248 (1992) 92 m.3 The (12Co/130) Ratio Towards Ophiuchi

92wrIA P.H.Hilliams, K.J.Robertson, A.Soutax,S.M.Gxiffin.A.R.L.Druffel, Prog.0ceanog. 30,253 (1992) Isotopic Signatures (1AC, $\left.13 C_{,}, 15 N\right)$ as Tracers of Scurces and Cycling of Soluble and particulate organic Natter in $92 \times 1 A 1$ Lhe Santa unica Basin, Califomia

High Precision Isotopic Measuremest Spctrom.Ion Proc. 116,183 (1992)

$92 x I A 2$ Y.Xiao,D.Sun, Y. Wang, H.Qi,L.Jin. Geochim.Cosmochim. Acta 56,1561 (1992) 92Yos1 Boron Tsotopic Compositions of Brine, Sediments, and Source Water in Da Qaidam Iake, Qinghai, China 
92ZHAI

92 ZAA2

922HR1

93A201

93BOI

93CHAL

93 CHE1

93CIAI

93k0m

93FARI

930ATI

93GRA1

93HAL1

93 Hor 1

93 Jorn

93 Kort

93LAKI

93LES1

931001

934ET1

$93 \mathrm{MTT1}$

931021

93PROI

$930 \mathrm{CA1}$

93RAOI

93ROs1

93 shI1

93SKI2

93 SUI I

93TAVI

9 JUAY I

V.A. Zharikov, Y.O.Dubinina, V.A. Suvorova Yu. B.Shapovalov, Geokhimiya 2 163 (1992)

Oxygen-Isotope Data on the Origin of the wineralizing Pluid at the Akchatau Rare-Netal Deposit

- F. Zheng, fur J Lineral 4.1331 (1992)

S.-1.Azuma H. Ozima, H.Hiyagon, Barth Planet.Sci.Lett. 114,341 (1993)

Anomalous Neon and Xenom in an Archaean Anorthosite Erom Nest Greenland

S.R.Boyd, A.Hall,C.T.Pillinger, Geochim_Cosmochim.Acta 57,1339 (1993)

Te Measurement of Delta $15 \mathrm{~N}$ in Crustal Rocks by Static Vacum Hase Spectrometry: Application to the Origin of the

-L.Chang, Q. - Y.Qian, H. -T.Zhao,J.Wang, Intern.J.hass Spectram. Ia Proc. 123,77 (1993)

The Isotopic Abumdance of Antimany

.H.Chen, D.J.DePaolo,S.Makada, Y, -N.Shieh, Nature 362,B31 (1993)

Relationship between Bruption Volume and Neciymium Isotopic Compositicn at Unzen Volcano

C.Class,S.L.Goldstein,S.J.G.Galer, D. Weis. Nature 362,715 (1993)

Y.U.H. Edwards,J.D.Morris, M.F.Thirlwall, Nature 363.530 (1993)

Separating Mantle frow Slab Signatures in Are Lavas dsing B/Be and Radiogenic Isotope Systematics

.A. Farley, R.J. Poreda, Barth Planet. Sci.I

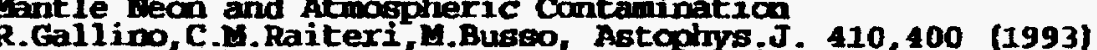

Carbon Stars and Igotopic Ba Anomalies in reteoritic Sic Grains

M.H.Grady,C.T.Pillinger Barth Planet.Sci.lett. 116165 (1993)

Acfer 182 : Search for the location of 15 - Enriched ifitrogen in an Urusual Chomdrite

A.F.Halliday,G.R.Davies,D.-C.Lee,S.Tommasini, C.R.Pasl ick, J.Godfrey,D.R.James, Nature 362, 184 (1993)

head Isotope Bvidence for Young Irace Blement Bnrichment in the Oceanic Dpper uantle

J.H.Hof fmain, A. O.Rier, Gecphys Res.Iett. 20,121 (1993)

tmospheric Helium Isotopic Ratio

.J.Johnsco, R.H.Goldistein, Nature 362,335 (1993)

Cambrian Sea hater Preserved as Inclugions in tarine Low-yagnesium Calcite Cement

J -Roziet, A Rosmman, G.J.Martin, P.R.Ashurst, Analytica Chin Acta 271, 31 (1993)

Determination of Carbon-13 Content of Sugars of Fruit and Vegetable Juices

.D.Langer. A.A. Penzias, Astrophys J 408,539 (1993)

12C/13C Isotope Ratio in the locai interstellar Eedium from Observations of $13 \mathrm{C} 180$ in ublecular clouds

R.A.Ieske, Astrcply.J. 405,567 (1993)

The Rlemental and sotcpic Composition of Galactic Cosmic-Ray Nuclei from Scandium Through nickel

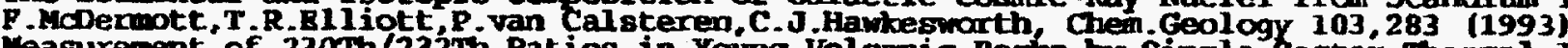

basurement of $230 \mathrm{Th} / 232 \mathrm{mh}$ Ratios in Young Volcanic Rocks by single-sector Thermal Ionisatica Kass Spectrametry

D.M. Meyer, I . Hawkins, B. L. Wright, Astrophys.J. 109,161 (1993)

The Interstellax $\%$ (Gli Inotope Ratio Toward zeta Ophiuchi and zata Persi

G. P. Witchell, J.-P. Maillard, Astrophy.J.

P.S.Moxiey,S.J.Bums, J.Sedimentary Petrol. 63,73 (1993)

axygen and Carbcn Isótopic Composition of Harine Carbonate Concretions: An Overviev

C.A.Prombo, F.A. Podosek, S. Amari, R.S. Iemis, Astropirys.J. 410, 393 (1993)

8 - Process Ba Isotopic Corpositions in Presolar siC from the Murchiscon veteorite

P.D.Quay, S. Fmersan, D.Wilbur,C.Stump, H. Knox, J.Gecphys, Res. 98, 8447 (1993)

The Delta iso of Dissolved on in the Surface Vaters of the Subarctic pacific: A Tracer of Biological Productivity

Solar-Flare-Iqplanted $4 \mathrm{He} / 3 \mathrm{ll}$ and Solar-Proton-Produced $\mathrm{Ne}$ and Ar Concentration Profiles Preserved in

Limar Rock 61016

.

Isotopic Bvidence for the source of Lead in Greenland Frous since the Late 1960s

M.Shima, N.Torigope, Intern.J.Mass Spectnom Ion Proc 123.29 (1993)

A. Shimoyama,H Maraoka, O. Yatsubaya, K.Harada, Chem. Tett. (Reprint) (1993)

V.V.Smith. D. A. Tambert, P.B.Higsen, Astrophys.J. 108,262 (1993)

The 6Li/7hi Ratio in the Letal-Poor Halo Dwarf HD 19445 and HD 84937

A.Taviani,D.R.Reid, J.B.Anderson, J.Sedimentary Petrol 63.84 (1993)

Skeletal and isotopic Composition and Paleoclimatic Sigmificance of Iate pleistocene Carbonates, Ross Sea.

Antarct ica

D.P.Taylor, Geochim. Cosmochim.Acta 57.503 (1993) 
91 FRE1

91FRY1

91FuKI

91GILI

91GIL2

91Gak1

9160N

91602

910001

91GRA

91GRI 1

916U 1

91HES1

911tar

91 HON1

91 rrome

91IAC1

91IRE1

91JEA

91 JRAI

91 Jom

91 KaI 1

91 KRL.

91KkT

91 KIRI

91KISI

91KUB1

$92 \mathrm{~km}$

$91 \mathrm{kOOI}$

91 KRAI
Isotoge Comoosition of Xe in the Host Acid-Resistant Fractions of the Yefremovka CV3 Chondrite K.H.Preeman, S.G.Wakeham Org.Geochem. 19,277 (1991)

vaciations in the Distributions and Isotopic Compositions of Alkenones in Black Sea Particles and Sediments B. Fry,H.W.Jannasch,S.J.Molyneaux, C.O.Wirgen,J.muramoto,S.King, Deep-Sea ReB. 38,S1003 (1991)

Stable Isotgpe Studies of the Carbon, Nitrogen and Sulfur Cycles in the Black Sea and the Cariaco Trench

. Fukumoto, K.Nagao, J-I.Matsuda, Geochim.Cosmochim.Acta 50, 2245 (1991)

Noble Gas Studies on the Host phase of High 3He/AHe Ratios in Deep-Sea Sediments

K.R.Gilroy, J.A.Brom, Astrophys.J. 371, 578 (1991)

I.Gilmour, I.A. Franchi,C.T.pillinger,P.Bakin,A.Falick, weteoritics 26,337 (1991)

Compound Specific Isotope Analysis of Polycyclic Aromatic flydrocarbons in Carbonaceous Chondrites

A.Gokce,B.Spiro, Mineral . Deposita 26, 30 (1991)

Sulfur Isotope Study of Source and Deposits of Stibnite in the Turhal Area, Turkey

L.A.Gonzalex, H.H.Ruiz, Gegphys.Res . Lett. 18.513 (1991)

Diagenesis of Hidale Tertiary Carbcnates in the Toa Baja Well, Puerto Rico

.A.Gonsalez, Geophys.Res.Iett. 18,533 (1991)

Carbon and oxygen stable

G.A.Goodfriend, Ouaternary Res. 35,417 (1991)

Holocene Trends in 180 in Iand Snail Shells from the Negev Desert and Their Implications for Changes in Rainfall Source Areas

T.Graf,C.P.Kohl, K.Marti, K. Nishilzumi, Geophys.Res.Lett. 18, 203 (1991)

Cosmic-Ray Protuced Neon in Antarctic Rocks

C. Wrinenko, V, F smolkin, Geokhimiya 9,30 (1991)

sotope Composition and Content of Sulfux in Pechenga-Zone Perropicrites and Gabbro-behrlites

4. - Yu, Chinese Science Bulletin 36,1979 (1991)

R. Hestermate I sotcpic Composition of the Losess-pal

Production and Stabe Isotopic Composition of $\mathrm{CO}_{2}$ in soil Near Bern. Svitzerland

G. Holdsworth, S.Pogarasi.H.R.Krouse, J.Geophys.Res - 96, D4, 7483 (1991)

Variation of the Stable Isotopes of Water with Altitude in the Saint Blias Hountains of Canada

M.Honda, I.McDougall,D.B.Patterson, A,Doulgeris,D.A.Clague, Nature 349,149 (1991)

Possible Solar Roble-Gas Component in Bavaiian Basalt

1. Fonma, H-Kusakabe, H. Kagami, S. Iizumi , H. Sakai Y. Kodama, M.Kimura Geochem.J. 25,121 (1991)

Major and Trace Element Chemistry and D/H, 180/160, 8jSr/86Sx and 143Nd/144Nd Ratios of Rocks from the Spreading

Center of the Okinaua Trough, A Larginal Back-Are Basin

. Iacumin, B.H.Picciril10,A.Ianginelli. Chem.Ceol. (Isotope Geosci.Sec.) 86, 225 (1991)

Oxygen Isotopic Composition of Iomer Cretacoous Tholeiites and Precambrian Basement Rocks fram Parana Basin

Brazil) : The Role of Water-Rock Interaction

.R.Ireland, B.K.Zinmer, S, Amari. Astrophys.J. 376,L53 (1991)

Isotopically Ancmalous Ti in Presolar SiC from the Murchison Neteorite

(1991)

23 Degree

C.K.C.Jen, G.H.R.Kegel, Nucl.Inst, Nethods Ptys, Res. B62,242 (1991)

reasurement: of the Lithiun Isotopic concentration

B.C.Jowett, T.Roth A.Rydzewaki S.Oszczepalaki, Mineral Deposita 26,89 (1991)

Background Del 345 Values of kupferschiefer Sulphides in Poland: Pyrite-Narcasite Nodules

H.K.Kai ser, I Hawkins, B. W. Wright, Astrophys-J. 379, 267 (1991)

The Interstellar $12 \mathrm{Cr} / 13 \mathrm{CH}$ Ratio Towand Persei

R.F.Kel1Y,R.G.Amundson, B.D.Larino,M.J.Deni ro, Quatemary Res, 35,222 (1991)

Stable Isotope Ratios of Carbon in Ptrytoliths as a quantitative Hethod of Monitoring Vegetation and Climate Change

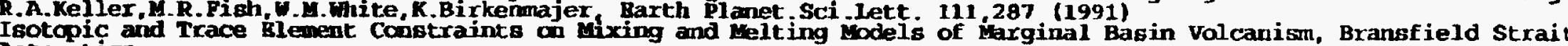

A.B.Kirkley, J.J.Guxney,M.I.Otter,S.J.Hi11,I.R.Daniels, Agp.Geochem-6,477 (1991)

The Application of $C$ Isotope Heasuxements to the Identiffcation of the Source of $C$ in Diamonds: A Review

Tariatev, M.A.Mikhaylov, A.A. Uishkin, M.G. Ukhaneva, Geophimiya 5, 742 (1991)

Variations in the Carbonate Carbon and axygen Isotopes in Far Bast Precambrian Sedimentary Series

Fractionation of oxygen Isotcpes at the paces of Smoky Quartz

C. Knudsen, B. Buchardt, Chem.Geology 86, 263 (1991)

Carbon and Oxygen Isotope Composition of Carbonate

Isotope Data on Organic Watter in Holocene Black
U. Kram, K.H. Wedepohl. Chem.Geology 90,253 (1991)

Sea

from the Qaqarssuk Carbonatite Camplex. Southern West Greenland 
The Isotopic Composition of Strontiun and Sulfur in Seawater of Late Permian (Zechstein) Age

911KCI

91 rong

91IAMI

91LEAL

91 LESB 1

911.6.

91 HarI

$9110 \mathrm{n}$

$910 \mathrm{xuc1}$

9LACI

91UARI

91 LAG1

g1MAK1

9IMAL1

91MARL

91MRR2

91MAR3

9 IMAR4

91MAT1

91MAT2

$91 \mathrm{LCC1}$

91 MCII

91 MIG1

$91 \mathrm{MOR}$

91Mos1

914052

91NEL,

91NIT1

91NOTI

91 NRI 1

Tuc. Tellus 43B,373 (1991)

Concentratica and Carbon Isotopic Copposition of Atmospheric 002 in Southem Poland

Variaticis in the 1900 s/1840s Ratio in Some Stone weteorites and Acid Residues of Sikhote Alin Iron veteorite A.Iamberty, P.De Bievre, Intern.J. Lass Spectrom. Ion Proc. 108, 189 (1991)

Isotope Difution Lass Spectrometry of $10 B$ and $6 \mathrm{hiF}$ Reference Deposits Used for the Determination of the Neutron

S.X. Ieayitt,A.Iong, Chem.Geology 87.59 (1991)

Seasconal Stable-Cábon Isotcpe Variability in Tree Rings: Rossible Raleoemvi:ommental Signals

.P. Leeman, R.D. Vocke,Jr., E.S.Beary, P.J.Paulsen, Geochim. Cosmochim. Acta 55, 3901 (1991)

Precise Boran Isotopic Analysis of Aqueous Samples: Ion Bxchange Bxtraction and pass Spectrometry

M. Legrand C. Feniet-Saigme, B.S. Saltzman C.Germain, N. I.Barkov, V.N.Petrov, Nature 350, 144 (1991)

Ice-Core Record of Dceanic Brissions of Dimethylsuiphide During the Iast Cilmate Cycle

M. Lehman, D.Siegenthaler. J.Glaciology 37,125 (1991)

Gquilibrium Oxygen- and Hyơrogen-Isotope Fractionation Between Ice and watex

D.C.Lome, C.A.M. Bremninkme jer,S.C.Tyler, R.J.Dlugokencky, J.Ceophys. Res. 96,15467 (1991)

Determination of the Isotopic composition of Atmogpheric wethane and Its Application in the Antarctic

First-Onder Orgenic Carbon budget in the st Iawrence Lomer Estuary from isc bata

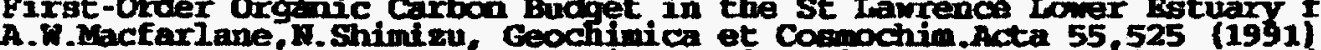

sins veasurements of Delta $34 \mathrm{~s}$ in Sulfide Hinerals from Adjacent vein and stratabound ores

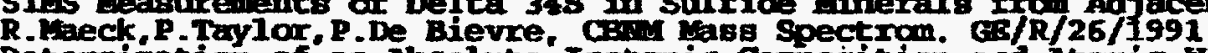

Determination of an Absoluter Isotopic Compoition and Atomic Weight of a Reference Sample of Natural Iron

H.Magritz,S.Rahmer, Y. Yechieli,R.V.Krighnamurthy, laturwissenschaften 78,453 (1991)

13C/12C Ratio in Organic satter from the Dead Sea Area: Paleoclimatic Interpuctation

A. Hakishima, R. Nakamura. Chem.Geol. 94.1 (1991)

Precise Eeasurement of Cerium Iootope Composition in Rock Samples

K.A.Maltsev, Geokhimiya 12,1795 (1991)

Nitrogen Aggregation and the Isotope Composition of Carbon and Nitrogen in Diamonds

B.D. Narino, IK.B.HcBlroy, Nature 349,127 (1991)

Isotopic Composition of Atmospheric CO2 Inferred from Carbon in C4 plant Cellulose

A.Mariotti, F.Gade1, P. Giresse, Kinga-Houzeo, Chem,Geol. (Isotope Geosci. Sect.) 86,345 (1991)

Carbon Isotope Conositicn and Geochemistry of Particulate Organic Iatter in the Congo River (Central Africa)

Application to the Study of Quaternary sediments off the Mouth of the River

L.A.Mart inelii,A.H.Devol, R.I.Victoria,J.F.Richey, Nature 353,57 (1991)

Stable Carbon Isotope variation in $C_{3}$ and $C 4$ Plants Along the Amazon River

C.B.Martin, Geochim.Cosmochim.Acta 55,1421 (1991)

Osmium Isotopic Characteristics of Lantle-Derived pocks

J. - I.Matsuda, T.Matoumoto, K. Nagao, Geochemical J. 24,379 (1991)

An At tempt to Detect 3 He from the Cold Muclear Fusiom

J. - I. Matsuda, K. Fukumaga, K. Ito, Geochim.Coemochim. Acta 55, 2011 (1991)

Noble Gas Studies in Vapor-Growth Diamonds: Comparison with Shock-produced Diamonds and the Origin of Diamonds in Ureilites

T.B.ucCandless, J.Ruiz. Geology 19,1225 (1991)

Ssmim Isotopes and Crustal Sources for Platinum-Group Mineralization in the Bushveld Complex, South Africa

N.J.Mchaughton, K.J.R.Rosman, Geochim.Cosmochim.Acta 55,499 (1991)

Tin Isotope Fractionation in Terrestrial Cassiterites

Z.M.Migaszemski, J.Geology 99,171 (1991)

Devonian Dolomites from the Holy Cross urs, Poland: A New Concept of the Orgini of Massive Dolomites Based on

Massive Dolomites Based on Petrographic and Isotopic Bvidence

C.I.Hora, S.G.Driese, P.G.Seager, Geology 19,1017 (1991)

Carbon Dioxide in the Paleozoic Atmosphere: Evidence from Carbon-Isotope Compositicns of Pedogenic Carbonate

M.Musashi. T.Oi, T.Ossaka, H.Kakihana, Isotopenpraxis 27,163 (1991)

Natural Bónon Isotope Practionation Between Hot Spxing Water and Rock in Direct contact

D.S. Wusselwhite, M.J.Drake.T.D.Swindle. Nature 352 697 (1991)

Early Outgassing of uars supported by Differential water Solubility of Iodine and Xenon

B.K. Helson,G.K. Nacleod, P.D. Ward, Nature 351 , 644 (1991)

Rapid Change in Strontium I iotopic Composition of Sea Water Before the Cretaceous/Tertiary Boundary

S. Nitz, H. Koll lmannsberger, B. Heinreich, F. Drawert, J.Chrcomatography 557, 187 (1991)

Enanticmeric Distribution and $13 \mathrm{C} / 12 \mathrm{C}$ Isotope Ratio Determination of Gama-lactones: Appropriate Methods for the Differentiation Between Naturai and Non-Natural Flavours?

K. Notsu,H. Waki ta, Y. Nakamura, App1.Geochem. 6,543 (1991)

Stront ium Isotopic Composition of Hot Spring and Hineral Spring waters, Japan

J.O.Nriagu, R.D. Coker, L.A.Barrie, Nature 349,142 (1991)

Origin of Sulphur in Caradian Arctic Haze from Isotope Measurements 